[DOI: 10.24214/jecet.A.9.3.43949.]

Jaurnal of Environmental Science, Computer Science and Engineering \& Technology

An International Peer Review E-3 Journal of Sciences and Technology

Available online at www.jecet.org

Section A: Environmental Science

Research Article

\title{
Length-weight relationships and condition factors of some species of fish of commercial interest caught in the upper Lualaba, part of Kindu (DR Congo)
}

\author{
Ngoy A Ngoy Chuck ${ }^{1 *}$, Luvengo Darabu Didier ${ }^{1}$, Mulungo Sangwa Hugues $^{1} \&$ \\ Doma Tana Anicet ${ }^{1,2}$ \\ ${ }^{1}$ Université de Kindu, Faculté des Sciences Agronomiques, Département de Zootechnie, \\ B.P.122, Kindu, RD Congo. \\ ${ }^{2}$ Université de Lubumbashi, Faculté des Sciences Agronomiques, Unité de recherche en \\ Biodiversité et Exploitation durable des Zones Humides (BEZHU), B.P. 1825, Lubumbashi, \\ RD Congo.
}

Received:15 May 2020; Revised:06 June 2020; Accepted: 14 June 2020

\begin{abstract}
In order to contribute to the evaluation of the biodiversity and growth of fish species in the Congo River, a study was conducted in Kindu in the Democratic Republic of Congo, from January 14 to June 28, 2019. The objective was to identify commercial fish species and assess their growth. For the realization of this study, a pre-survey and field observations were carried out at the central Beach of Kindu, place of sale of caught fish which were the subject of our study during the rainy season. In fact, 110 specimens were caught with hawk nets, monofilament gill nets and hooks ( ${ }^{\circ} 16,18$ and 20).The results obtained showed that six species of fish of commercial interest were inventoried: Distichodus engycephalus (24.5\%), Synodontis decorus and Auchenoglanis occidentalis (with 20.9\% each), Oreochromis niloticus and Sarotherodon galileus (commonly 15, 5\%) and finally Labeo macrostomus (2.7\%). Oreochromis niloticus, Sarotherodon galileus, Distichodus engycephalus, Labeo macrostomus and Auchenoglanis occidentalis had positive allometric growth
\end{abstract}


(83.3\%) and Synodontis decorus, isometric growth (16.7\%). Thus, all of the species of fish of commercial interest studied adapt well to the environmental conditions of the environment. Therefore, subsequent studies on the biology (diet and reproduction) of these fish species are however necessary in order to consider their domestication.

Keywords: Biodiversity, growth, fish, commercial interest, Congo river, Kindu.

\section{INTRODUCTION}

The notion of biodiversity is currently widely publicized and there is concern about the disappearance of certain known and not yet described species ${ }^{[1]}$. Despite this, certain groups of organisms, such as freshwater fish from the Congo Basin, remain poorly understood, yet they present remarkable diversity ${ }^{[1]}$. As a result, various studies try to define and specify this ichthyological diversity, in order to be able to protect it ${ }^{[2]}$.

The imperfect knowledge of fish species, and the absence of data on their distribution and abundance make any decision to difficult decisions for their conservation. The composition of fish fauna depends on factors such as geographic distribution, type of ecosystem and environmental characteristics ${ }^{[3]}$. In developing countries already facing the problems of shortage of drinking water and pollution, climate change by disturbing numerous ecosystems, contribute to the accentuation of phenomena and especially the disturbance of aquatic ecosystems ${ }^{[4,5]}$.

After the Amazon basin ${ }^{[6,7]}$, the Congo basin, whose area is estimated at 3,067,000 km2, is the most diverse in the world for freshwater fish species ${ }^{[8-10]}$. Its straddling position on the equator and the almost homogeneous distribution of its tributaries in the two hemispheres regulate its water flow and make it the most regular river in the world ${ }^{[8]}$. Its watershed covers a vast area, $62 \%$ of which is in DR Congo and is teeming with biodiversity and significant endemicity ${ }^{[8]}$.

However, for about a decade, knowledge of the upper ichthyological settlement of the Lualaba in its part of Kindu has been unknown, although some efforts are currently being made by researchers from the Faculty of Agronomic Sciences at Kindu University, concerns studies on the inventory, biology and ecology of fish in the rivers of Kindu and its surroundings ${ }^{[11,12]}$.

Studies on the diversity and dynamics of fish species provide essential information for decisionmaking for the implementation of policies and programs for the sustainable management of fishery and aquaculture resources ${ }^{[13]}$. Indeed, they make it possible to analyze the structure and the dynamics of fish populations, to assess mortality and to estimate production in order to develop management strategies ${ }^{[14.15]}$.

However, the evaluation of the growth of fish species uses the approach of size structure, lengthweight relationships and condition factors. Several authors ${ }^{[16-18]}$ emphasize that the differences in growth observed in fish are strongly linked to habitat quality, seasons ${ }^{[19]}$, age and physiological state as well as sex ${ }^{[9]}$.

Length-weight relationships and condition factors for Kindu stream fish species are nonexistent. It therefore appears desirable to identify the species of fish of economic interest caught in the upper Lualaba and to assess the length-weight relationships and condition factors thereof. 


\section{MATERIALS AND METHODS}

2.1. Study environment: The town of Kindu, chief town of the province of Maniema, is located on a latitude of $22^{\circ} 56^{\prime} 37^{\prime \prime}$ 'South; a longitude of $25^{\circ} 55^{\prime} 20^{\prime \prime}$ East, an altitude of $497 \mathrm{~m}$ and an area of $101,295 \mathrm{~km} 2{ }^{[20]}$. According to the Köppen classification, the city of Kindu belongs to the Aw type climate which corresponds to the hot and humid tropical climate. The temperature varies between 23 and $35^{\circ} \mathrm{C}^{[20]}$. Its hydrographic network is very dense and structured around the Congo River also called Lualaba superior. This river is fed by its main tributaries including the rivers Kasuku, Elila, Ulindi, Lufubu, Lowe, Lowa, Musukuyi, Mulongoy, etc. ${ }^{[20]}$.

The study fish were paid to local fishermen operating along the Congo River, in the Kindu part, more precisely at the central Beach. The choice of this fish collection site was motivated by the landing of many pirogue fishermen.

2.2. Fish collection: Before collecting the study specimens, a few species of economically interesting fish caught in the Lualaba were identified by a preliminary survey of fishmongers. It consisted of a direct interview between investigator and respondent on species of fish of lucrative interest.

Due to the lack of scientific fishing gear, the study fish were paid to local fishermen using hawk nets, monofilament gill nets of different meshes and hooks ( ${ }^{\circ} 16,18$ and 20) during the rainy season from January at the end of June 2019.

A total of 110 specimens made up the study sample. After harvest, the fish species were stored in $10 \%$ diluted formalin for later identification in the laboratory. The collected fish were weighed individually using a $0.1 \mathrm{~g}$ precision digital scale, SCA-301 brand, and measured using $1 \mathrm{~mm}$ precision paper. The standard length measured is a horizontal distance from the anterior end of the snout to the base of the caudal fin. The standard length variable was taken in millimeters and then converted to centimeters. Thus, the identification of the collected fish was done using identification keys such as: Fauna of freshwater and brackish fish from West Africa ${ }^{[21]}$; Freshwater and brackish fish from Lower Guinea, West Central Africa ${ }^{[22]}$ and fish from the Congolese part of Inkisi ${ }^{[8]}$.

2.3. Statistical data analysis: Length-weight relationships are generally exponential to assess the growth of fish populations. The regression curves of type $\mathrm{P}=\mathrm{aLSb}$ are obtained from length-weight pairs, where P represents the weight of the individual $(\mathrm{g}), \mathrm{LS}$ the standard length $(\mathrm{cm})$, has the initial growth coefficient and $\mathrm{b}$ the slope from the regression line. After logarithmic transformation in the form: $(\log \mathrm{P}=\log \mathrm{a}+\log \mathrm{b})$, the parameters $\mathrm{a}$ and $\mathrm{b}$ for each of the length-weight equations were estimated by analyzes of linear regressions ${ }^{[23]}$.

The length-weight relationships reflect isometric growth when the value of $b$ is equal to 3 and allometric growth when the values of $b$ are greater than or less than 3. However, a positive allometric growth is observed when $b$ is greater than 3 and a negative allometric growth when $b$ is less than $3^{\text {[24- }}$ ${ }^{26]}$. Likewise, the $95 \%$ confidence interval of $a$ and $b$ was estimated; the statistical difference between the value of $\mathrm{b}$ for each of the species and the isometric value $(\mathrm{b}=3)$ was obtained using the Student's $\mathrm{t}$ test carried out according to this formula Sokal \& Rohlf ${ }^{[27]}:$ ts $=(b-3) / E S b$, where ts is the value of Student's test; $b$ is the slope of the regression line and ESb is the standard error of $b$. All the tests were significant at the 5\% level ( $\mathrm{p}<0.05)$. Biometric fish growth indices were processed and analyzed using Excel software (2007 version) and Statview version 1992-98 (SAS Institute INC). 
The study of condition factors has the importance of: (i) comparing mono-specific populations living in apparently similar or different conditions, and (ii) monitoring the increase and decline of feeding ${ }^{[28]}$. The overweight condition of the fish caught in the Lualaba was assessed using the formula $\mathrm{K}=$ $(100 \mathrm{P} / \mathrm{LSb})^{[29,30]}$.

\section{RESULTS}

3.1. Inventory of some species of fish of economic interest: Reading the results shown in Table 1, the species Distichodus engycephalus is more represented with 24.5\%; followed by Synodontis decorus and Auchenoglanis occidentalis with $20.9 \%$ each; then Oreochromis niloticus and sarotherodon galileus with commonly $15.5 \%$ and finally Labeo macrostomus $2.7 \%$.

3.2. Length-weight relationship data: The results obtained emphasize that the average of the coefficients of determination $\mathrm{r} 2$ for all the species studied is 0.910 . Notwithstanding, the minimum and maximum values of $\mathrm{r} 2$ vary from 0.841 to 0.995 respectively for $\mathrm{A}$. occidentalis and $\mathrm{L}$. macrostomus. Of all the fish species caught, only $S$. decorus has isometric growth $(\mathrm{b}=3 ; \mathrm{p}>0.05)$ and five other species including O. niloticus, S. galileus, D. engycephalus, L. macrostomus and A. occidentalis have positive allometric growth ( $>3$; $\mathrm{p}<0.05)$. The species $S$. decorus has a low value of $\mathrm{b}=2.408$ compared to that of L. macrostomus which is 3.284 .

Regarding the student t test (ts) of all species, $S$. decorus has a higher value (2.740) and the low value is found in D. Engycephalus (0.512). Almost all of the species including O. niloticus, S. galileus, D. engycephalus, L. macrostomus and A. occidentalis have positive allometric growth of $83.3 \%$ and a single species of $S$. decorus has isometric growth of $16,7 \%$.

3.3. Condition coefficients $(K)$ and biometric indices of the inventoried species: The condition factors of all the species studied varied between 1.4 and 10.1. Thus, the species L. macrostomus has a lower value and the higher value is noticed in $O$. niloticus.

Table 1: List of fish species of economic interest inventoried in the upper Lualaba, in its part of Kindu during January to June 2019. \%: percentage.

\begin{tabular}{llcc}
\hline Familles & \multicolumn{1}{c}{ Espèces } & Effectif & \% \\
\hline Cichlidae & Oreochromis niloticus & 17 & 15,5 \\
& Sarotherodon galileus & 17 & 15,5 \\
Distichodontidae & Distichodus engycephalus & 27 & 24,5 \\
Mochokidae & Synodontis decorus & 23 & 20,9 \\
Cyprinidae & Labeo macrostomus & 3 & 2,7 \\
Auchenoglanidae & Auchenoglanis occidentalis & 23 & 20,9 \\
\hline Total & \multicolumn{1}{c}{$\mathbf{0 6}$} & $\mathbf{1 1 0}$ & $\mathbf{1 0 0}$ \\
\hline
\end{tabular}


Table 2: Estimated parameters of the length-weight relationship of some species of commercial interest inventoried n: number of specimens; a: growth coefficient; b: slope of the regression line; CI: confidence interval; ES: standard error; r2: coefficient of determination; ts: student test; A +: positive allometry; I: isometry.

\begin{tabular}{|c|c|c|c|c|c|c|c|c|c|c|}
\hline Familles & Espèces & $\mathbf{n}$ & $a$ & IC de $a$ à $95 \%$ & $\boldsymbol{b}$ & IC de $b$ à $95 \%$ & ES de $b$ & $\mathbf{r}^{2}$ & ts & croissance \\
\hline \multirow{2}{*}{ Cichlidae } & Oreochromis niloticus & 17 & 0,096 & $0,031-0,298$ & 2,522 & $1,954-3,089$ & 0,266 & 0,856 & 1,796 & $\mathrm{~A}+$ \\
\hline & Sarotherodon galileus & 17 & 0,021 & $0,013-0,036$ & 3,227 & $2,966-3,488$ & 0,122 & 0,978 & 1,860 & $\mathrm{~A}+$ \\
\hline Distichodontidae & Distichodus engycephalus & 27 & 0,032 & $0,017-0,059$ & 2,921 & $2,603-3,239$ & 0,154 & 0,934 & 0,512 & $\mathrm{~A}+$ \\
\hline Mochokidae & Synodontis decorus & 23 & 0,089 & $0,031-0,259$ & 2,408 & $1,960-2,856$ & 0,216 & 0,856 & 2,740 & I \\
\hline Cyprinidae & Labeo macrostomus & 3 & 0,014 & $3,138^{\mathrm{E}-5}-6,009$ & 3,284 & $0,409-6,160$ & 0,226 & 0,995 & 1,256 & $\mathrm{~A}+$ \\
\hline Auchenoglanidae & Auchenoglanis occidentalis & 23 & 0,037 & $0,011-0,130$ & 2,767 & $2,222-3,311$ & 0,262 & 0,841 & 0,889 & $\mathrm{~A}+$ \\
\hline
\end{tabular}


Table 3: Parameters of condition coefficients and average biometric indices of fish species of commercial interest.LS: standard length; K: condition coefficient; Min: minimum; Max: maximum; Moy : moyenne ; DS: standard deviation.

\begin{tabular}{llccccc}
\hline Familles & Espèces & \multicolumn{3}{c}{ LS (cm) } & \multicolumn{3}{c}{ Poids (g) } \\
\cline { 3 - 7 } & & K & Min-Max & Moy \pm DS & Min-Max & Moy \pm DS \\
\hline \multirow{2}{*}{ Cichlidae } & Oreochromis niloticus & 10,1 & $5,8-9,5$ & $7,3 \pm 1,1$ & $7,0-23,0$ & $15,4 \pm 5,6$ \\
& Sarotherodon galileus & 2,4 & $5,4-9,5$ & $7,3 \pm 1,4$ & $5,0-36,0$ & $15,1 \pm 10,0$ \\
Distichodontidae & Distichodus engycephalus & 3,5 & $4,0-9,5$ & $6,9 \pm 1,3$ & $2,0-25,0$ & $10,3 \pm 5,8$ \\
Mochokidae & Synodontis decorus & 9,1 & $8,5-12,5$ & $10,7 \pm 1,0$ & $15,0-44,0$ & $28,0 \pm 6,6$ \\
Cyprinidae & Labeo macrostomus & 1,4 & $7,7-9,2$ & $8,3 \pm 0,7$ & $11,0-20,0$ & $14,6 \pm 4,7$ \\
Auchenoglanidae & Auchenoglanis occidentalis & 4,1 & $7,0-14,0$ & $10,0 \pm 1,8$ & $8,0-63,0$ & $24,7 \pm 14,5$ \\
\hline
\end{tabular}




\section{DISCUSSION}

The present study demonstrates the presence of fish species of commercial interest in the Congo River, most of which are endemic, as the authors point out ${ }^{[31-33]}$.

Lowe-MacConnell ${ }^{[34]}$ criticizes that the presence or absence of certain species of fish of commercial interest in the Congo River is the consequence of the flood or the low water due to the change of seasons during a period of the year.

Even, seasonal changes in water level with the creation of long-term flood plains have an impact on the functioning of tropical hydro-systems. Also, periodic flood-low alternations favor the creation of varied habitats with a major impact on the biology, physiology and ecology of fish populations. ${ }^{[35]}$

The authors ${ }^{[36,37]}$ emphasize that the allometric coefficients are strongly linked to water quality parameters, sex, growth phase, stomach contents, development gonads and availability of food. The species O. niloticus, S. galileus, D. engycephalus, L. macrostomus and A. occidentalis showed a positive allometric ( $>3 ; \mathrm{p}<0.05$ ) characterized by a growth in weight much greater than that in length. However, these results are similar to those of $\mathrm{Da}$ et al. ${ }^{[38]}$ in $\mathrm{S}$. galileus caught in the Kompienga reservoir in Burkina Faso; Adebolaet al. ${ }^{[39]}$ in O. niloticus from the ERO reservoir in Nigeria.

On the other hand, the allometric coefficients $(b<3 ; p<0.05)$ indicate negative allometric growth in the work of Getso et al. ${ }^{[40]}$ in O. niloticus from the Wudil river in Nigeria; Hazoum et al. ${ }^{[41]}$ in $O$. niloticus from the Sô river in Benin; Hazoum et al. ${ }^{[41]}$ in Sarotherodon melanotheron of the Sô river in Benin. The values of isometric growth coefficient $(b=3 ; p>0.05)$ were recorded in S. decorus. Contrary results with negative allometric growth have been reported in Synodontis nigrita from the Sô river in Benin ${ }^{[41,42]}$; Akombo et al. ${ }^{[42]}$ at Synodontis schall of the Benue river in Makurdi in Nigeria.

The condition coefficient is a nutrition index which gives a good idea of the overweight of the fish ${ }^{[43]}$. According to Bagenal \& $\operatorname{Tesch}^{[29]}$, the values between 2.9 and 4.8 are consistent for the freshwater fish species. Our results revealed that all fish species have a condition factor varying between 1.4 and 10.1. These similar values have been reported by Da et al. ${ }^{[38]}$ in S. galileus caught in Lake Bam and the Kompienga reservoir in Burkina Faso; Akombo et al. ${ }^{[42]}$ at Synodontis schall of the Benue river in Makurdi in Nigeria; Egbal et al. ${ }^{[44]}$ in O. niloticusd e the Atbara river and the Khashm El-Girba reservoir in Sudan.

\section{CONCLUSION}

This study provides the first information on length-weight relationships and condition coefficients of some species of economically interesting fish caught in the upper Lualaba, in its part of Kindu. Its purpose was to identify fish species of economic interest and assess their growth in order to build a data bank.The results obtained indicate that $D$. engycephalus is the most captured species in the Lualaba. The length-weight relationships of fish collected have shown that almost all the species studied have positive allometric growth, except in the species of the family Mochokidae (S. decorus) whose growth is isometric. The results of condition coefficients have shown that all the species studied live in good environmental conditions. 


\section{ACKNOLRDGMENT}

We would like to thank Mr. Muzito Sebastien for his availability and participation during the various downhill collections of study fish species.

\section{RÉFÉRENCES}

1. J.P.Sullivan, S.Lavoué \&J.P.Friel, A la découverte des poissons du parc national d'Odzala. Canopée Bulletin sur l'Environnement en Afrique Centrale, 2004, 17-21.

2. J.P. Sullivan, Quand les poissons apportent leurs premières pierres et leurs premiers signaux électriques, corneluniversity USA1-4,2001

3. Dejoux, L.Lauzanne \&C. Lévêque, Evaluation qualitative et quantitative de la faune benthique dans la partie Est du Lac Tchad", Cah.OSRSTOM, Sér.Hydrobiol, 1969, 3,3-58.

4. J. Morel, Les ressources en eau sur terre : origine, utilisation et perspectives dans le contexte du changement climatique un tour d'horizon de la littérature. Grenoble" : CRNS, Cahier de recherche, 2007, $\mathrm{N}^{\circ} 2,29 \mathrm{p}$.

5. Foto, T. Zebaze, T. Nyamsi, G. Ajeagah,T. Njiné, Evolution de la diversité des peuplements de macroinvertébrés benthiques dans un cours d'eau Anthropisé en milieu tropical(Cameroun) ", European journal of scientific reaseach, 2011,55 ,2, 291-300.

6. B.Hugueny \&C. Lévêque, Richesse en espèces des peuplements des poissons. Pp. 263 è277. In : Lévêque C. \&Paugy D. (eds). Les poissons des eaux continentales africaines ; Diversité, Ecologie, Utilisation par l'homme. IRD Editions, Institut de Recherche pour le Développement, Paris, 2006,573p.

7. T. Oberdorff, P.Tedesco, B. Hugueny, F. Leprieur, O.Beauchard, S.Brosse, \&H. Durr, Global and Regional Patterns in Riverine Fish Species Richness: A Review. International Journal of Ecology, 2011: Article ID 967631: 1-12.

8. D.Musibono, Contribution à l'étude écologique des poissons de la partie congolaise de l'Inkisi. Thèsedoctorale/ULG-Belgique, 2004, 87-226.

9. C. Lévêque \&D. Paugy, Distribution géographique et affinités des poissons d'eau douce africains, pp. 59-74. In : Lévêque C. \&Paugy D., éds. Les poissons deseaux continentales africaines: diversité, écologie et utilisation par l'homme. IRD, Paris, 2006, 564p.

10. T.J.Flügel, F.D.Eckardt \&F.P.D.Cotterill,The Present Day Drainage Patterns of the Congo River System and their Neogene Evolution.Geology and Resource Potential of the Congo Basin, Regional Geology Reviews,2015,DOI 10.1007/978-3-642-29482-2-15.

11. [30] Manga T.J., Nyongombe U.N. \& Mulungo S.H., 2013. Identification des poissons capturés dans le fleuve Congo et vendus dans la ville de Kindu: Cas de Beach Central de Kindu et Beach Basoko,. Revue Shaloom de Développement, Editions Universitaires Shaloom de Bunia, lère Année, $N^{\circ} 001$, , pp. pp 97-112.

12. T.Manga, Biologie, écologie et commercialisation des poissons prélevés dans le fleuve Congo à Kindu (Maniema) et vendus dans les marchés de Kindu. Thèse de doctorat : Université de Kisangani, Gestion des Ressources Naturelles et renouvelables, Kisangani (RDCongo), 2015, $191 \mathrm{p}$. 
13. A.K.V.Nasser, Length-weight relationships of tuna baitfish from the Lakshadweep Islands, India. Naga, ICLARM Q., 1999, 22: 42-44.

14. C.Lévêque \&D. Paugy, Les Poissons des Eaux Continentales Africaines. Diversité, Ecologie, Utilisation par l'Homme. IRD: Paris, France, 1999a

15. J.M.Lorenzo, J.G.Pajuelo, M. Mendez-Villamil, J. Coca. et A.G.Ramos ,Age, growth, reproduction and mortality of the striped seabream, Lithognathusmormyrus (Pisces, Sparidae), off the Canary Islands (Central-east Atlantic). J. Appl. Ichthyol., 2002, 18: 204209.

16. R. Amara, T. Meziane, C. Gilliers, G. Hermel \& P.Laffargue, Growth and condition indices in juvenile sole Solea soleameasured to assess the quality of essential fish habitat. Mar EcolProgSer., 2007,351: 201-208. DOI: http://dx.doi.org/10.3354/meps07154.

17. I.I.Toko,E,Y, Attakpa\&H. Elegbe, Performances biologiques, zootechniques et nutritionnelles de Tilapiaguineensis en milieux naturel et d'élevage. International Journal Biological and Chemical Sciences.2010, 4(5): 1629-1640. http://dx.doi.org/1 0.4314/ijbcs. v4i5. 65577.

18. F.Kapute, J. Valeta, J. Likongwe, J. Kang, J. Nagoli \& D. Mbamba, Growth performance of three tilapia fishspeciesraisedatvaried pond sizes and water depths. International Journal of Fisheries and Aquaculture, 2016, 8(8): 81-86. DOI: http://dx.doi.org /10.5897/IJFA2016.0566.

19. N.G. Aliko, K.S. Da Costa, Y.M. Dietoa, A. Ouattara, G. Gourène. Caractéristiques de la population de Distichodus rostratus Günther, 1864 (pisces: Distichodontidae) du lac de barrage de Taabo (bassin du Bandama, Côte d'Ivoire). Implications pour une gestion rationnelle du stock. Tropicultura, 2010, 28(1): 50-56. Doi : 10.1007/BF00006595.

20. Anonyme, Monographie de la province du Maniema, Espace et vies, Le Cri édition, Musée Royal de l'Afrique Centrale de Tervuren, 2004, p.10.

21. C. Lévèque, D. Paugy \&G.G.Teugels (eds), 1990-1992. Faune des Poissons d'eaux douces et saumâtres de l'Afrique de l'Ouest. 910 p. Paris: ORSTOM, 1990.

22. G. Stiassny, L. Melanie, D. Teugels \& Hopkinsal, Poissons d'eaux douces et saumâtres de basse Guinée, ouest de l'Afrique centrale, 2007, I. 75231, Paris cedex 05.

23. J.H. Zar, Biostatistical Analysis.4th Edition. Prentice-Hall, Englewood Cliffs, New Jersey, 1999, USA.662 pp.

24. J.C. Micha, Etude des populations piscicoles de l'Oubangui et tentative de sélection et d'adaptation de quelques espèces à l'étang de pisciculture. Centre Technique Forestière tropicale, Norgent sur Marne, 1973, 100p.

25. W.E.Ricker, Calcul et interprétation des statistiques biologiques des populations de poissons. Bulletins de l'office des recherches sur les pêcheries du Canada, 1980, 191F, Ottawa.

26. A.W.Shingleton, Allometry: the study of biological Scaling. Nature Education Knowledge, 2010, 3(10): 2.

27. R. Sokal \&F. Rohlf, Introduction to Biostatistics. Freeman, New York, USA, 1987.

28. J.Didier \&J.C.Micha, Dynamique de population du gardon en Meuse et stratégie de gestion. Presses Universitaires de Namur, ETEC, 1996, p103. 
29. T.B. Bagenal \& A. T.Tesch, Conditions and Growth Patterns in Fresh Water Habitats. Blackwell Scientific Publications, Oxford, 1978, 75-89.

30. E.Baijot, J. Moreau \& S. Bouda, Aspects hydro biologiques et piscicoles des retenues d'eau en zone soudano-sahélienne, 1994.

31. C. Lévêque \&D. Paugy,. Biogéographie et mise en place des faunes ichtyologiques actuelles. In: Les Poissons des Eaux continentales africaines. Diversité, Écologie, Utilisation par l'Homme (Lévêque C. \& D. Paugy, eds), Paris:Édition IRD, 1999b, 61-81.

32. M. Hanssens, E. Vreven \&J. Snoecks, The Ithyofauna of Lower Congo and Pool,2004.

33. Eli, List of Freshwater Fishes for Dem. Rep. of Congo, www.fishbase.org,2008.

34. R.H.Lowe-MacConnel, Broad characteristics of the ichthyofauna. In: Lévêque C, Bruton MN. \&Ssentongo GW. (eds) : Biology and ecology of African freshwater fishes. Paris, Orstom, Travaux et documents, 1988, 216, Pp. 93-110. Malebo, 13 Benelux Congress of Zoology, November 5-6; Louvain-la Neuve.

35. C. Lévêque \&D. Paugy, Fish communities in river systems and associated biotopes. In: Paugy D, Leveque C. \& Otero O. (eds): The inland water fishes of Africa: Diversity, Ecology and Human use, Institut de Recherche pour le Développement (IRD), Royal Museum for Central Africa (RMCA), 2017, 349-360.

36. M.Y. Hossain , Z.F.Ahmed , P.M. Leunda, S. Jasmine, J. Oscoz, R. Miranda \& J. Ohtomi, Condition, length-weight and length-lengthrelationships of the Asianstripedcatfish Mystusvittatus (Bloch, 1794) (Siluriformes: Bagridae) in the Mathabhanga River, Southwestern Bangladesh. Journal of AppliedIchthyology, 2006, 22 : 304-307.

37. Y.I.Yakubu, B.N.Oluranti, J. Ewutanure \&U. Rilwan, Food Habit and Growth Pattern of Oreochromisniloticus in Wase Dam, Nigeria. Nature and Science, 2016, 14(12) : 46-49. DOI: http://dx.doi.org/10.1007/s11160-009-9152-z

38. N. Da, R. Ouédraogo \&A. Ouéda, Relation poids-longueuret facteur de condition de Clariasanguillaris et Sarotherodongalilaeus pêchées dans le lac Bam et le reservoir de la Kompienga au Burkina Faso. International Journal Biological and Chemical Sciences. 2018, 12 (4): 1601-1610, August 2018.

39. T. Adebola, O.A.Bello-Olusoji, A.O.Fagbenro \& T.A.Sabejeje, Length-Weight Relationship and Condition Factor of Four Commercially Important Fish Species at ERO Reservoir, Ekiti State, Nigeria. International Journal of Innovative Research \& Development, 2016,5.

40. B.U.Getso, J.M.Abdullahi \&I.A.Yola, Length-Weight relationship and condition factor of Clariasgariepinus and Oreochromisniloticus of Wudilriver, Kano, Nigeria. ISSN 1119-7455. Agro-Science Journal of Tropical Agriculture, Food, Environment and Extension 2017, 16 ,14

41. R.U.S.Hazoume, A.Chikou, C. Koudenoukpo, P.Houndonougbo, A.Adite, C.A.Bonou \& G.A.Mensah, Length-weight relationships of 30 species of fish of theriver Sô in Benin (West Africa). International Journal of Fisheries and Aquatic Studies 2017; 5(3): 514-519

42. River Benue at Makurdi, Nigeria. International Journal of Fisheries and Aquatic Studies 2014; 1(3): 42-48. 
43. E.D. Le Cren, The length-weight relationship and seasonal cycle in gonad weight and condition in perca (Percafluviatilis). Journal of Animal Ecology, 1951, 20: 201-219.

44. O.A.Egbal, E.A.Mohammed \&A.A.Afra, Length-Weight relationships and condition factors of six fishspecies in Atbara River and Khashm El-Girba reservoir, Sudan. International Journal of Agriculture Sciences, 2011, 3, 65-70.

\section{* Corresponding Author: Ngoy A Ngoy Chuck ${ }^{1}$}

${ }^{1}$ Université de Kindu, Faculté des Sciences Agronomiques, Département de Zootechnie, B.P.122, Kindu, RD Congo.

Date of publication on line 14.06.2020 